\title{
Association of Biometric Traits with Growth Hormone Gene Diversity in Raini Cashmere Goats
}

\section{Fatemeh Gholamhoseinzadeh GOOKI ${ }^{1}$, Mohammadreza MOHAMMADABADI ${ }^{1, *}$, Masoud Asadi FOZI ${ }^{1}$ and Mohammad SOFLAEI ${ }^{2}$}

\author{
${ }^{\text {I} D e p a r t m e n t ~ o f ~ A n i m a l ~ S c i e n c e, ~ F a c u l t y ~ o f ~ A g r i c u l t u r e, ~ S h a h i d ~ B a h o n a r ~ U n i v e r s i t y ~ o f ~ K e r m a n, ~}$ \\ Kerman, Iran \\ ${ }^{2}$ Kerman Agricultural and Natural Resources Research and Education Center, AREEO, Kerman, Iran
}

('Corresponding author's e-mail: mmohammadabadi@yahoo.ca,mrm@uk.ac.ir)

Received: 16 April 2017, Revised: 24 September 2018, Accepted: 7 October 2018

\begin{abstract}
In recent years, the important effects of growth hormone on a broad variety of physiological parameters, such as lactation, reproduction, growth, and metabolism, have attracted many researchers' attentions. To detect GH gene polymorphism and its association with the biometric traits of Raini Cashmere goats, 300 animals were selected and the animals' genotype was determined using PCR-RFLP. Two different genotypes (AA and $\mathrm{AB}$ ) were observed in exons 2 and 3 within the goat $G H$ gene. The genotype frequencies for $\mathrm{AA}, \mathrm{AB}$, and $\mathrm{BB}$ were $0.15,0.85$, and 0 , and frequencies of the $\mathrm{A}$ and $\mathrm{B}$ alleles were 0.575 and 0.425 , respectively. The number of observed alleles, number of effective alleles, expected heterozygosity, observed heterozygosity, mean of heterozygosity, expected homozygosity, observed homozygosity, Nei's index, Shannon's index, and Fixation index (Fis) were 2, 1.96, 0.49, 0.85, 0.49, $0.51,0.15,0.49,0.69$, and -0.74 , respectively. Birth type had a significant effect on the Chest height to earth $(\mathrm{T} 26)$ trait $(\mathrm{P}$-value $=0.032304)$. Furthermore, a significant effect of age on some biometric traits were observed in this study. The frequency of the AB genotype for most of the traits were higher in comparison to the AA genotype, although some traits did not show a significant effect, which might be explained by the heterosis phenomenon. According to the results, it can be concluded that allele A of growth hormone is a suitable allele for the THH (Toe height of hand hoof), THF (Toe height of foot hoof), HHF (Heel height of foot hoof), and CHE (Chest height to earth) traits, and allele B is a worthy allele for the NI (Nasal interval), LCI (Lip corner interval), NL (Neck length), CC (Chest circumference), AC (Abdominal circumference), LLF (Leg length of foot), WHC (Wither height to under the chest), and DAD (Dorsal angle distance of scapula to Hänsch point) traits. Therefore, better results in the breeding programs for these traits can be achieved from this information, along with other phenotypic records.
\end{abstract}

Keywords: PCR-RFLP, Raini Cashmere goat, birth weight, fleece weight, birth type

\section{Introduction}

Goat farming is a common and popular practice in the world, with goat products having a favorable image. The number of goats has increased globally, despite major changes in agriculture due to industrial mergers, globalization, and technological advances in developed countries [1]. There are 30 million heads of Cashmere goats around the world, with 4.5 - 5 million heads of them in Iran, which is $20 \%$ of all Cashmere goats in the world [2]. Goat production is one of the key elements contributing to the economy of farmers living in arid and semi-arid regions, including most areas of Iran. The Raini goat is one of the most important Iranian native breeds that are distributed in the southeast of Iran, where these animals are kept for milk, meat, and Cashmere production [3]. One of the most important purposes of the genetic 
improvement of this breed is to enhance meat production through programmed and accurate selection. On the other hands, determination of gene polymorphism is important in farm animal breeding [4-6] in order to define genotypes of animals and their associations with productive, reproductive, and economic traits. Growth hormone $(\mathrm{GH})$ has an effect on a broad variety of physiological parameters, such as lactation, reproduction, growth, and metabolism [7]. The GH gene has 2544 bp length, including 4 introns and 5 exons [8], and its polymorphisms have been reported in cattle [9,10], sheep [11], and goats [7]. Yamano et al. [12] and Yato et al. [13] described the sequence of goat pituitary growth hormone cDNA, and Kioka et al. [14] introduced the GH gene sequence. In some other studies, the association among genetic polymorphism of GH and plasma levels [10,15], milk production [16-18], milk protein percentages [19], litter size and weight [8,20], superovulation [20], and chest and paunch girth [21] have been reported. Although many studies have been done on Raini Cashmere goats [22-27], no studies concerning the polymorphisms of GH gene in Raini Cashmere goats and its association with biometric traits has been published. Therefore, the goal of this study was to describe the association of the GH gene diversity with the biometric traits of Raini Cashmere goats for the first time.

\section{Materials and methods}

The study was done using 300 female Raini Cashmere goats, age between 38 to 92 months, from a breeding station for Raini goats in Baft City (middle of Kerman Province, Iran). The animals' birth types had 2 levels, single and twin. Blood samples were collected from the jugular vein of the animals into vacutainers, with EDTA as the anticoagulant. The samples were kept at $-20{ }^{\circ} \mathrm{C}$ until analysis. DNA was extracted from the whole blood using an optimized and modified salting-out method [28].

A 422-bp fragment encoding exons 2 and 3 within the goat $G H$ gene was amplified using PCR primers 5'-CTCTGCCTGCCCTGGACT-3' and 5'-GGAGAAGCAGAAGGCAACC-3' [29]. The PCR amplification was performed in a $25 \mu \mathrm{l}$ reaction volume, containing negative controls, using CinnaGen PCR Master Kit according to the instructions of the manufacturer (CinnaGen Co., Iran). Initial denaturation for $5 \mathrm{~min}$ at $94{ }^{\circ} \mathrm{C}$ was followed by 35 cycles of $30 \mathrm{~s}$ at $95{ }^{\circ} \mathrm{C}, 30 \mathrm{~s}$ at $64{ }^{\circ} \mathrm{C}, 45 \mathrm{~s}$ at $72{ }^{\circ} \mathrm{C}$, and a 7 min final extension step at $72^{\circ} \mathrm{C}$.

Amplification products were electrophoresed on $2 \%$ agarose gel at constant voltage and $1 \mathrm{X}$ TBE for approximately $2 \mathrm{~h}$. The gels were visualized by staining with ethidium bromide and photographed under ultraviolet light; then, all PCR products were digested with $10 \mathrm{U}$ of HaeIII enzyme (Fermentas) at $37{ }^{\circ} \mathrm{C}$ overnight, and the resulting products were separated by the $3.5 \%$ agarose gel and visualized by ethidium bromide staining. Measurement of diversity, including gene diversity $(\mathrm{H})$, the observed number of alleles (Ne), Shannon's information index, etc., were estimated by the POPGEN 3.2 software [30]. Association analyses of the GH gene polymorphism, with 29 biometric traits (Table 1), were performed for the 300 Raini Cashmere goats, using the following univariate animal model;

$\mathrm{y}=\mathrm{Xb}+\mathrm{Z}_{1} \mathrm{u}+\mathrm{Z}_{2} \mathrm{~m}+\mathrm{Z}_{3} \mathrm{mpe}+\mathrm{Z}_{4} \mathrm{pe}+\mathrm{e}$

where $\mathrm{y}$ is a vector of animal records, $\mathrm{b}$ is a vector of fixed effects, $\mathrm{u}$ is a vector of additive genetics effects, $\mathrm{m}$ is a vector of maternal genetics effects, mpe is a vector of permanent environmental effects of dams, pe is a vector of animal permanent environmental effects, and e is a vector of residual effects. X, $Z_{1}, Z_{2}, Z_{3}$, and $Z_{4}$ are incidence matrices. ASReml [31] was used for the analysis. 
http://wjst.wu.ac.th

Table 1 Characteristics of biometric traits.

\begin{tabular}{|c|c|c|c|c|c|}
\hline \multicolumn{3}{|c|}{ Trait } & \multicolumn{3}{|c|}{ Trait } \\
\hline Number & Name & Abbreviation & Number & Trait name & Abbreviation \\
\hline T1 & Ear length & EL & T16 & Wrist length of hand & WLH \\
\hline $\mathrm{T} 2$ & Ears interval & EI & $\mathrm{T} 17$ & Toe height of hand hoof & $\mathrm{THH}$ \\
\hline $\mathrm{T} 3$ & Face length & FL & $\mathrm{T} 18$ & Heel height of hand hoof & $\mathrm{HHH}$ \\
\hline $\mathrm{T} 4$ & Eyes interval & YI & T19 & Leg length of foot & LLF \\
\hline T5 & Face width & FW & $\mathrm{T} 20$ & Leg circumference of foot & LCF \\
\hline T6 & Jaws interval & $\mathrm{JI}$ & $\mathrm{T} 21$ & Wrist length of foot & WLF \\
\hline $\mathrm{T} 7$ & $\begin{array}{l}\text { Nasal interval: Interval from } \\
\text { the front of nozzle to behind } \\
\text { the ears, from the face side }\end{array}$ & NI & $\mathrm{T} 22$ & Toe height of foot hoof & THF \\
\hline T8 & $\begin{array}{l}\text { Lip corner interval: Lip } \\
\text { corner interval to behind the } \\
\text { ears, from the face side }\end{array}$ & LCI & $\mathrm{T} 23$ & Heel height of foot hoof & $\mathrm{HHF}$ \\
\hline T9 & Neck length & NL & $\mathrm{T} 24$ & Wither height to earth & WHE \\
\hline $\mathrm{T} 10$ & Neck circumference & $\mathrm{NC}$ & $\mathrm{T} 25$ & $\begin{array}{l}\text { Wither height to under the } \\
\text { chest }\end{array}$ & WHC \\
\hline $\mathrm{T} 11$ & Neck width & NW & $\mathrm{T} 26$ & Chest height to earth & $\mathrm{CHE}$ \\
\hline $\mathrm{T} 12$ & Chest circumference & $\mathrm{CC}$ & $\mathrm{T} 27$ & $\begin{array}{l}\text { Chest distance from back of } \\
\text { thigh }\end{array}$ & CDT \\
\hline T13 & Abdominal circumference & $\mathrm{AC}$ & $\mathrm{T} 28$ & $\begin{array}{l}\text { Dorsal angle distance of } \\
\text { scapula to Hänsch point }\end{array}$ & DAD \\
\hline T14 & Leg length of hand & LLH & T29 & $\begin{array}{l}\text { Hänsch distance to end of } \\
\text { Hamstring }\end{array}$ & $\mathrm{HDH}$ \\
\hline $\mathrm{T} 15$ & Leg circumference of hand & $\mathrm{LCH}$ & & & \\
\hline
\end{tabular}

\section{Results and discussion}

The extracted DNA had good quality (Figure 1). The tested DNA was amplified using the specific primers and yielded PCR products at the expected size, 422 bp (Figure 1).

Amplification of exons 2 and 3 produced 422 bp fragments. When these fragments were digested with the restriction enzyme, the AA genotype produced 2 bands: 366 and $56 \mathrm{bp}$ (one restriction site in the $\mathrm{B}$ allele), the BB genotype produced one band: $422 \mathrm{bp}$ (no restriction sites in the $\mathrm{B}$ allele), and the $\mathrm{AB}$ produced 3 bands: 422, 366, and $56 \mathrm{bp}$ (heterozygote genotype). The different alleles resulting from digestion of the PCR products with the HaeIII restriction enzyme after running on the agarose gel electrophoresis are presented in Figure 2.

The genotypic and allelic frequencies of exons 2 and 3 within the goat GH gene in Raini Cashmere goats in Kerman are shown in Table 2. Sampling fluctuations might also have contributed to the differences in allelic frequencies in the population.

In this study, the Hardy Weinberg equilibrium was estimated with the chi-square test and the likelihood ratio test. The value of chi-square was 163.18 , greater than the critical value. The likelihood ratio test was estimated as 210.35 , greater than the critical value. The population under this study was not found to be in a Hardy-Weinberg equilibrium (Table 3), as for years it has been under selection for production and reproduction traits.

The values of the population genetics parameters in the Raini Cashmere goat population for the GH gene were as follow: Numbers of observed alleles, 2; number of effective alleles, 1.96; expected heterozygosity, 0.49; observed heterozygosity, 0.85; mean of heterozygosity, 0.49; expected homozygosity, 0.51; observed homozygosity, 0.15; Nei's index, 0.49, and Shannon's index, 0.69. Fixation index (Fis) as a measure of heterozygote deficiency for the A and B alleles was -0.74 . 
http://wjst.wu.ac.th

In this research, the association between $\mathrm{GH}$ gene polymorphism and biometric traits was studied using a univariate animal model. Birth type had a significant effect only on the Chest height to earth (T26) trait $(\mathrm{P}$-value $=0.032304)$. The age also had a significant effect on some biometric traits (Table 4). Face length (T3), Nasal interval: Interval from the front of nozzle to behind the ears, from the face side (T7), Lip corner interval: Lip corner interval to behind the ears, from the face side (T8), Neck length (T9), Chest circumference (T12), Abdominal circumference (T13), Wither height to under the chest (T25), and Dorsal angle distance of scapula to Hänsch point (T28) were higher in the older animals, which can be caused by differences in physiologic and genetic reactions, such as hormone secretions at different ages. Therefore, it can be concluded that age is an important factor affecting the biometric traits of animals. Each of the studied traits are differentiated and develop at different ages. Some of the traits are matured and stop growing at early ages, and the rest at later ages. These results are in agreement with the results of Wiener et al. [32] and Yakubu et al. [33], who showed that the evolution of body traits occurs in mammals before puberty, and that growth continues to pre-puberty over a specific pattern and then stops.

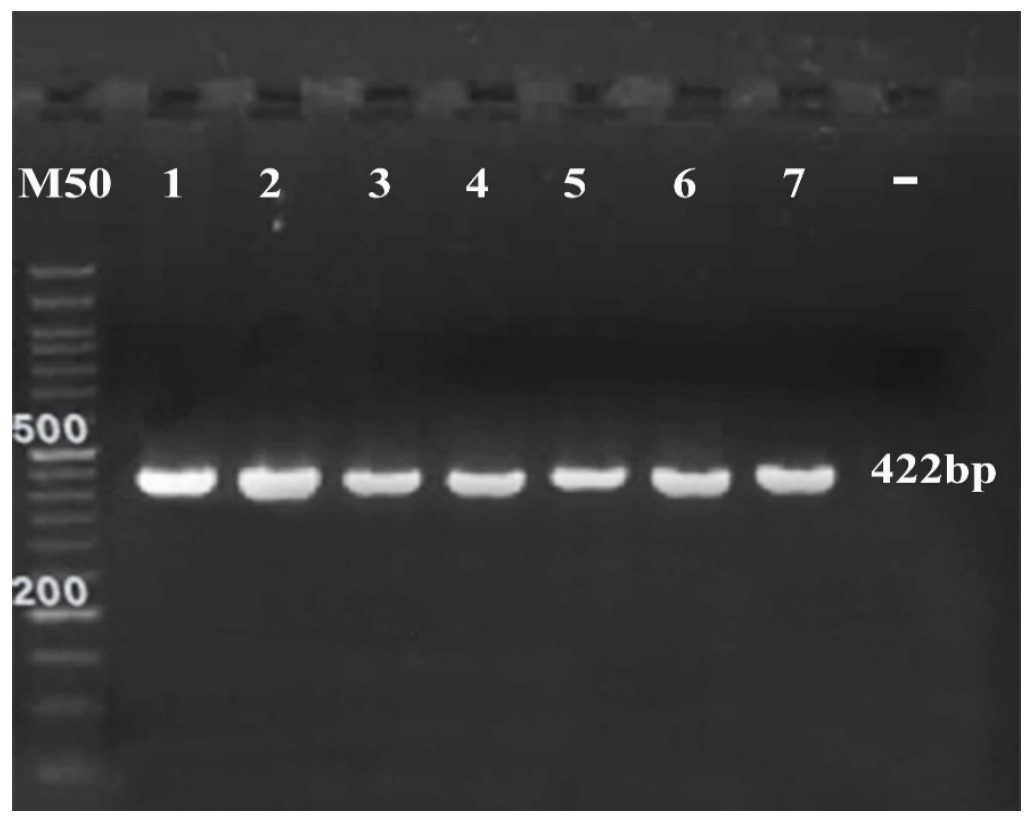

Figure 1 Ethidium bromide-stained agarose gel of amplified PCR products representing amplification of exons 2 and 3 within the goat GH gene in Raini Cashmere goats in Kerman, Iran. The size marker is the M50. Lanes $1-7$ are 422 bp PCR products amplified from the DNA of the studied goats, and - is a negative control. 


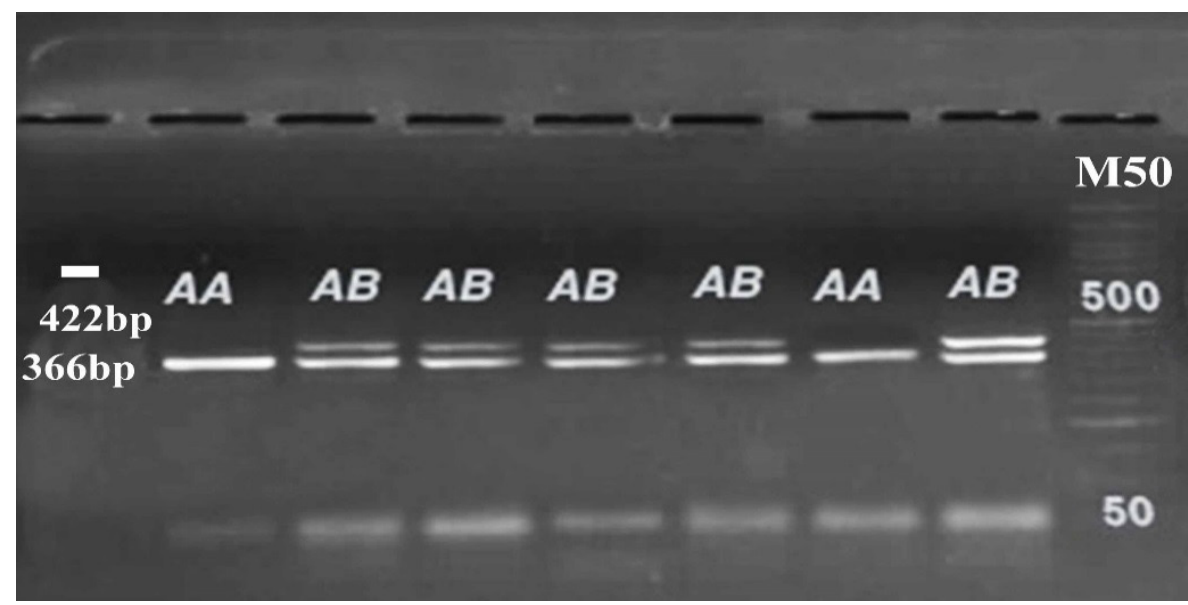

Figure 2 PCR amplified products of exons 2 and 3 within the goat GH gene in Raini Cashmere goats in Kerman, Iran, digested with HaeIII. The size marker is M50, - is a negative control, and other lanes are $\mathrm{AA}$ and $\mathrm{AB}$ genotypes.

Table 2 The genotype and allele frequencies of the GH gene in Raini Cashmere goats in the Kerman province of Iran.

\begin{tabular}{ccccc}
\hline Genotype & Number of genotypes & Genotype frequencies & Allele & Allele frequencies \\
\hline AA & 45 & 0.15 & A & 0.575 \\
AB & 255 & 0.85 & B & 0.425 \\
Total & 300 & 1 & & \\
\hline
\end{tabular}

Table 3 K-square and G-square tests values in Raini Cashmere goats in the Kerman province of Iran for the Hardy-Weinberg equilibrium.

\begin{tabular}{cccc}
\hline K-square value & G-square value & Degree of freedom & $\mathbf{0 . 0 5}$ probability level \\
\hline 10.471 & 10.733 & 1 & 0.001 \\
\hline
\end{tabular}

Table 4 Biometric traits affected by age.

\begin{tabular}{|c|c|c|c|}
\hline Number & Name & Abbreviation & P-value \\
\hline $\mathrm{T} 3$ & Face length & FL & 0.046698 \\
\hline $\mathrm{T} 7$ & $\begin{array}{l}\text { Nasal interval: Interval from the front of nozzle to behind } \\
\text { the ears, from the face side }\end{array}$ & NI & $3.32588 \mathrm{E}-05$ \\
\hline $\mathrm{T} 8$ & $\begin{array}{l}\text { Lip corner interval: Lip corner interval to behind the ears, } \\
\text { from the face side }\end{array}$ & LCI & $8.48167 \mathrm{E}-05$ \\
\hline T9 & Neck length & NL & 0.026687 \\
\hline $\mathrm{T} 12$ & Chest circumference & $\mathrm{CC}$ & 0.048584 \\
\hline T13 & Abdominal circumference & $\mathrm{AC}$ & 0.031969 \\
\hline $\mathrm{T} 25$ & Wither height to under the chest & WHC & 0.034156 \\
\hline $\mathrm{T} 28$ & Dorsal angle distance of scapula to Hänsch point & DAD & 0.046698 \\
\hline
\end{tabular}


The results of the current study are in agreement with some other studies. For example, Boujenane and Hazzabs [34] showed that the birth weight in the Draa goat breed for males was $19 \%$ higher than for females. Boer goats, Barbari goats, and Iraq native goat males also had higher birth weights than females [35-37]. Fleece weight difference between males and females in one-year-old Australian goats was reported as 51 grams [38]. Walkden-Brown et al. [39] demonstrated that the least square means of fleece weight in male Australian Angora goats of different ages is higher than in females. Allain and Roguet [40] also reported that male French Angora goats produced 250 grams more fleece than females. In other studies, Meybodi [41] and Nejad and Fozi [42] reported the difference between male and female fleece weights in Raini Cashmere goats as 66.62 and 40 grams, respectively.

The results of our study showed that growth hormone genotypes had different effects on biometric traits in different genotypes (Table 5).

Generally, the AB genotype had a higher amount than the AA genotype, but for some traits had not shown significant effects (Table 5), which could be due to the heterosis phenomenon. It can be demonstrated that using different animals in breeding programs could result in heterotic achievement.

Only for traits T17 (Toe height of hand hoof), T22 (Toe height of foot hoof), T23 (Heel height of foot hoof), and T26 (Chest height to earth) did the AA genotype have higher amounts than the AB genotype; this difference was very low, and was not significant $(\mathrm{P}>0.05)$. More efficient traits are used in breeding programs [43]. Accordingly, T17 (Toe height of hand hoof), T22 (Toe height of foot hoof), T23 (Heel height of foot hoof) and T26 (Chest height to earth) traits can be considered in breeding programs in order to produce goats with higher heights at early ages economically. These results are consistent with the results of other researchers [44-46].

The studies of Singh et al. [21] on the association of GH gene polymorphism with chest and paunch girth in Sirohi and Barbari breeds of goats revealed significant breed differences for the least squares means of chest girth at each age, so that the measured traits for Sirohi kids were significantly higher than those for Barbari kids. In this study, the least square means for genotype AB was numerically higher than BB for chest girth at all ages, which is in agreement with the present findings on Raini Cashmere goats.

The least square analysis of variance conducted to analyze the association of polymorphic variants of the GH gene with paunch girth at birth to 180 days of age showed a highly significant effect $(\mathrm{P}<0.01)$ of breed on paunch girth at each stage. The least square means of paunch girth revealed significant breed differences at each age; Sirohi kids measuring significantly higher than Barbari kids. Although the least square means for the $\mathrm{AB}$ and $\mathrm{BB}$ genotypes did not differ significantly at any stage, the genotype $\mathrm{AB}$ was constantly superior over all the intervals for paunch girth [21].

In another study on Nanjiang Huang goats, Deng et al. [47] found significant effects of genotypes on chest girth at 2 months of age. Furthermore, in the study by Zhang et al. [48] on the IGF-I gene of Guanzhong goats (a gene similar to the GH gene in its effect), polymorphism, a significant $(\mathrm{P}<0.05)$ effect of genotype on chest circumference, was reported.

Wickramaratne et al. [49] reported non-significant differences for chest girth at 2 months of age between different genotypes involving single nucleotide polymorphisms at different regions of GH genes in the Sangamneri breed of goat.

Hua et al. [29] also detected $\mathrm{AA}$ and $\mathrm{AB}$ genotypes in Boer goat bucks and showed that $\mathrm{AB}$ genotype individuals tended to have a better performance, although no significant differences were observed $(\mathrm{P}>0.05)$. Furthermore, in another study on exons $1-5$ of the growth hormone in Serrana goats, Marques et al. [18] introduced 10 genotypes, from which $96 \%$ were heterozygote, which confirmed our results. Saleha et al. [50] studied exon 2 of the growth hormone gene in 4 Egyptian and Swedish goat breeds and showed that the frequency of allele A was higher than allele B in the Zaribi and Masri breeds, which agrees with our results, but not with the results from the study on the Barki and Ardi breeds, in which the frequency of allele B was higher than of allele A. It should be noted that allele frequencies of a gene based on the breeding strategies and programs used in different flocks and breeds, which in turn associate with the tastes and eating habits of each region of the world, may be changed by economic conditions and other factors in the future.

According to the data presented in Table 4, it can be concluded that allele A of the growth hormone is a suitable allele for T17 (Toe height of hand hoof), T22 (Toe height of foot hoof), T23 (Heel height of 
http://wjst.wu.ac.th

foot hoof), and T26 (Chest height to earth) traits, and allele B is a worthy allele for T7 (Nasal interval), T8 (Lip corner interval), T9 (Neck length), T12 (Chest circumference), T13 (Abdominal circumference), T19 (Leg length of foot), T25 (Wither height to under the chest), and T28 (Dorsal angle distance of scapula to Hänsch point) traits.

Table 5 Effects of growth hormone genotypes on the studied biometric traits.

\begin{tabular}{|c|c|c|c|}
\hline Biometric traits (cm) & Genotype & $\frac{\mathbf{A A}}{\operatorname{LSM} \pm \mathbf{S E}}$ & 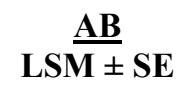 \\
\hline $\mathrm{T} 1$ & NS & $17.17 \pm 0.89$ & $18.04 \pm 1.83$ \\
\hline $\mathrm{T} 2$ & NS & $11.44 \pm 0.55$ & $11.63 \pm 1.13$ \\
\hline T3 & NS & $29.03 \pm 0.15$ & $29.30 \pm 0.31$ \\
\hline $\mathrm{T} 4$ & NS & $10.11 \pm 0.22$ & $10.22 \pm 0.45$ \\
\hline T5 & NS & $9.56 \pm 0.23$ & $9.94 \pm 0.48$ \\
\hline T6 & NS & $8.17 \pm 0.27$ & $8.29 \pm 0.56$ \\
\hline $\mathrm{T} 7$ & $*$ & $24.90 \pm 0.18$ & $25.35 \pm 0.37$ \\
\hline T8 & $*$ & $19.23 \pm 0.16$ & $19.59 \pm 0.32$ \\
\hline T9 & $* *$ & $29.09 \pm 0.25$ & $29.80 \pm 0.51$ \\
\hline $\mathrm{T} 10$ & NS & $32.22 \pm 0.95$ & $32.62 \pm 1.95$ \\
\hline T11 & NS & $27.33 \pm 1.27$ & $28.22 \pm 2.7$ \\
\hline T12 & $* *$ & $76.91 \pm 0.44$ & $78.33 \pm 0.91$ \\
\hline $\mathrm{T} 13$ & $*$ & $91.97 \pm 0.72$ & $93.87 \pm 1.48$ \\
\hline T14 & NS & $12.11 \pm 0.26$ & $12.41 \pm 0.54$ \\
\hline $\mathrm{T} 15$ & NS & $7.44 \pm 0.14$ & $7.44 \pm 0.28$ \\
\hline T16 & NS & $5.17 \pm 0.23$ & $5.21 \pm 0.47$ \\
\hline $\mathrm{T} 17$ & NS & $4.22 \pm 0.22$ & $4.02 \pm 0.45$ \\
\hline T18 & NS & $2.11 \pm 0.13$ & $2.19 \pm 0.27$ \\
\hline T19 & $*$ & $13.06 \pm 0.26$ & $13.72 \pm 0.54$ \\
\hline $\mathrm{T} 20$ & NS & $7.78 \pm 0.27$ & $8.13 \pm 0.55$ \\
\hline $\mathrm{T} 21$ & NS & $4.83 \pm 0.20$ & $4.93 \pm 0.41$ \\
\hline $\mathrm{T} 22$ & NS & $3.61 \pm 0.17$ & $3.59 \pm 0.35$ \\
\hline $\mathrm{T} 23$ & NS & $1.94 \pm 0.14$ & $1.87 \pm 0.28$ \\
\hline $\mathrm{T} 24$ & NS & $61.83 \pm 1.15$ & $62.33 \pm 2.36$ \\
\hline $\mathrm{T} 25$ & $* *$ & $33.05 \pm 0.19$ & $33.75 \pm 0.39$ \\
\hline T26 & NS & $33.13 \pm 0.33$ & $33.13 \pm 0.68$ \\
\hline $\mathrm{T} 27$ & NS & $64.28 \pm 1.52$ & $85.60 \pm 3.12$ \\
\hline $\mathrm{T} 28$ & $*$ & $47.09 \pm 0.41$ & $48.00 \pm 0.85$ \\
\hline T29 & NS & $14.33 \pm 0.43$ & $14.90 \pm 0.88$ \\
\hline
\end{tabular}

Hence, breeding programs of these traits can benefit from this information, along with other phenotypic records. In the studied population, Shannon's index and expected heterozygosity were estimated at 0.69 and 0.49 , respectively, which represents a relatively high diversity in this population. Due to the relatively high diversity of the growth hormone gene in Raini Cashmere goats and its association with important economic traits, using growth the hormone gene in breeding programs of these breeds can lead to acceptable genetic progress. Furthermore, applying the AA genotype for traits including T17 (Nasal interval: Interval from the front of nozzle to behind the ears, from the face side), T22 (Toe height of foot hoof), T23 (Heel height of foot hoof), and T26 (Chest height to earth) traits, and the AB genotype for T7 (Nasal interval), T8 (Lip corner interval), T9 (Neck length), T12 (Chest circumference), T13 (Abdominal circumference), T19 (Leg length of foot), T25 (Wither height to under 
http://wjst.wu.ac.th

the chest), and T28 (Dorsal angle distance of scapula to Hänsch point) can be used as an indirect marker for the selection of superior animals. These results might be explained by the genetic structure of the animals or the different expression patterns and levels of genes under various environments, where interactions of genotype and environment affect the physiology of animals, which results in different phenotypes.

\section{Conclusions}

The PCR restriction fragment length polymorphism technique used in this experiment proved to be an appropriate technique for screening samples for polymorphism with respect to the exon 2 and exon 3 regions of the $\mathrm{GH}$ gene. Moreover, the studied traits are polygenic traits and are controlled by many loci. However, the results of this study indicated that the growth hormone gene had effects on biometric traits. Thus, the polymorphism of the studied locus can be used to increase incidentally the accuracy of selection, genetic progress, and response to selection for these traits. Furthermore, although polymorphism data achieved from a locus is important for studying its effect on desired traits, it cannot be used alone as a selection criterion in practical conditions, and it is essential to use data from the studied locus along with information from other examined loci. Also, as the study was based on a limited sample size, further study on a larger sample is suggested. Our further study will be focused on the functional differences between the genotypes of this locus within the goat $G H$ gene.

\section{Acknowledgements}

The authors are grateful to the breeding station of Raini goats in Baft City (middle of Kerman Province, Iran) for providing the data. They also acknowledge the genetic lab crew for their assistance through the study.

\section{References}

[1] S Shamsalddini, MR Mohammadabadi and AK Esmailizadeh. Polymorphism of the prolactin gene and its effect on fiber traits in goat. Russ. J. Genet. 2016; 52, 405-8.

[2] A Baghizadeh, M Bahaaddini, MR Mohamadabadi and N Askari. Allelic Variations in Exon 2 of Caprine MHC Class II DRB3 Gene in Raeini Cashmere goat. Am. J. Agric. Environ. Sci. 2009; 6, 454-9.

[3] M Moghadaszadeh, MR Mohammadabadi and AK Esmailizadeh. Association of exon 2 of BMP15 gene with the litter size in the Raini Cashmere goat. Genetics in the 3rd Millennium 2015; 13, 4062 7 .

[4] MN Ruzina, TA Shtyfurko, MR Mohammadabadi, OB Gendzhieva, T Tsedev and GE Sulimova. Polymorphism of the BOLA-DRB3 gene in the Mongolian, Kalmyk, and Yakut cattle breeds. Russ. J. Genet. 2010; 46, 456-63.

[5] MR Mohammadabadi, N Askari, A Baghizadeh and AK Esmailizadeh. A directed search around caprine candidate loci provided evidence for microsatellites linkage to growth and Cashmere yield in Rayini goats. Small Rumin. Res. 2009; 81, 146-51.

[6] B Soufy, MR Mohammadabadi, K Shojaeyan, A Baghizadeh, S Ferasaty, N Askari and O Dayani. Evaluation of myostatin gene polymorphism in Sanjabi sheep by PCR-RFLP method. Anim. Sci. Res. 2009; 19, 81-9.

[7] A Mousavizadeh, MR Mohammadabadi, A Torabi, MR Nassiry, H Ghiasi and AK Esmailizadeh. Genetic polymorphism at the growth hormone locus in Iranian talli goats by Polymerase Chain Reaction-Single Strand Conformation Polymorphism (PCR-SSCP). Iran J. Biotech. 2009; 7, 51-3.

[8] XY Lan, H Chen, CY Pan, LJ Ming, CZ Lei, LS Hua, CL Zhang and SR Hu. Polymorphism in growth hormone gene and its association with production traits in goats. J. Appl. Anim. Res. 2007; 32, 55-60.

[9] MR Mohammadabadi, A Torabi, M Tahmourespoor, A Baghizadeh, AK Esmailizadeh and A Mohammadi. Analysis of bovine growth hormone gene polymorphism of local and Holstein cattle 
breeds in Kerman province of Iran using polymerase chain reaction restriction fragment length polymorphism (PCR-RFLP). Afr. J. Biotech. 2010; 9, 6848-52.

[10] P Schlee, R Graml, E Schallenberger, D Schams, O Rottmann, A OlbrichBludau and F Pirchner. Growth hormone and Insulin-like growth factor I concentrations in bull of various growth hormone genotypes. Theor. Appl. Genet. 1994; 88, 497-503.

[11] A Valinsky, M Shani and E Gootwine. Restriction fragment length polymorphism in sheep at the growth hormone locus is the result of variation in gene number. Anim. Biotech. 1990; 1, 135-44.

[12] Y Yamano, K Oyabayashi, M Okuno, M Yato, N Kioka, E Manabe, H Hashi, H Sakai, T Komano, K Utsumi and A Iritani. Cloning and sequencing of cdna that encodes goat growth hormone. 1988, 228, 301-4.

[13] M Yato, Y Yamano, K Oyabayashi, M Okuno, N Kioka, E Manabe, H Hashi, H Sakai, T Komano, K Utsumi, K Utsumi and A Iritani. Nucleotide sequence of the growth hormone gene cdna from goat Tokara. Nucleic Acids Res. 1988; 16, 3578.

[14] N Kioka, E Manabe, M Abe, H Hashi, M Yato, M Okuno, Y Yamano, H Sakai, T Komano, K Utsumi and A Iritani. Cloning and sequencing of goat growth hormone gene. Agric. Biol. Chem. 1989; 53, 1583-7.

[15] HM Zhang, DR Brown, SK DeNise and RL Ax. Nucleotide sequence determination of a bovine somatotropin allele. Anim. Genet. 1992; 23, 578.

[16] MA Meybodi. 1993, The Estimate Genetic Parameters for some Economic Traits in Raieni Cashmere Goats. MSC Thesis, Ferdowsi University, Mashhad, Iran.

[17] E Malveiro, M Pereira, PX Marques, I Santos, CC Belo, R Renaville and AC Cravador. Polymorphisms at the five exons of the growth hormone gene in the algarvia goat: Possible association with milk traits. Small Rumin. Res. 2001; 41, 163-70.

[19] PX Marques, M Pereira, MR Marques, IC Santos, CC Belo, R Renaville and A Cravador. Association of milk traits with SSCP polymorphisms at the growth hormone gene in the Serrana goat. Small Rumin. Res. 2003; 50, 177-85.

[18] A Lagziel, E Lipkin and M Soller. Association between sscp haplotypes at the bovine growth hormone gene and milk protein percentage. Genetics 1996; 142, 945-51.

[20] Ch Zhang, Y Liu, K Huang, W Zeng, D Xu, Q Wen and L Yang. The association of two single nucleotide polymorphisms (SNPs) in growth hormone $(\mathrm{GH})$ gene with litter size and superovulation response in goat-breeds. Genet. Mol. Biol. 2011; 34, 49-55.

[21] PP Singh, SS Tomar, MS Thakur and A Kumar. Polymorphism and association of growth hormone gene with growth traits in Sirohi and Barbari breeds of goat. Vet. World 2015; 8, 382-7.

[22] N Askari, MR Mohammadabadi, MR Nassiry, A Baghizadeh and J Fayazi. Study of genetic diversity of Raeini Cashmere goat based on microsatellite markers. J. Agric. Sci. 2009; 18, 155-61.

[23] N Askari, A Baghizadeh and MR Mohammadabadi. Analysis of the genetic structure of Iranian indigenous Raeni Cashmere goat populations using microsatellite markers. Biotechnology 2008; 2 , $1-4$.

[24] N Askari, A Baghizadeh and MR Mohammadabadi. Study of genetic diversity in four populations of Raeini Cashmere goat using ISSR markers. Modern Genet. 2010; 5, 49-56.

[25] MN Hassani, M Asadi Fozi, AK Esmailizadeh and MR Mohammadabadi. A genetic analysis of growth traits in Raieni Cashmere goat using multivariate animal model. Iran. J. Anim. Sci. 2010; 41, 323-9.

[26] MR Mohammadabadi. Relationships of IGFBP-3 gene polymorphism with Cashmere traits in Raini Cashmere goat. Modern Genet. 2012; 7, 115-20.

[27] F Tohidi nezhad, MR Mohammadabadi, AK Esmailizadeh and AN Noori. A Comparison of different levels of Rheb gene expression in different tissues of Raini Cashmir goat. J. Agric. Biotech. 2015; 6, 35-50.

[28] SA Miller, DD Dykes and HF Polesky. A simple sating out procedure for extracting DNA from human nucleated cells. Nucleic Acids Res. 1988; 16, $12-5$. 
[29] GH Hua, SL Chen, JN Yu, KL Cai, CJ Wu, QL Li, CY Zhang, AX Liang, L Hana, LY Geng, Z Shen, DQ Xu and LG Yang. Polymorphism of the growth hormone gene and its association with growth traits in Boer goat bucks. Meat Sci. 2009; 81, 391-5.

[30] FC Yeh, RC Yang and T Boyle. PopGene, Microsoft Windows based Freeware for Population Genetic Analysis. Release 131, University of Alberta, Canada, 1999.

[31] AR Glimur, BR Cullis and R Thompson. ASReml User Guide. NSW Department of Industry and Investment, VSN International, Hemel Hempstead, UK.

[32] G Wiener, GJ Lee and JA Woolliams. Effects of rapid inbreeding and of crossing inbred lines on the growth of linear body dimensions of sheep. Anim. Prod. 1992; 55, 101-4.

[33] A Yakubu, AE Salako and AR Abdullah. Varimax rotated principal component analysis of the zoometrical traits of Uda sheep. Arch. Zootec. 2011; 60, 813-6.

[34] I Boujenane and AE Hazzab. Genetic parameter for direct and mater effect on body weight of Draa goat. Small Rumin. Res. 2008; 69, 149-56.

[35] Z Chungyan, Y Ligu and S Zhang. Variance components and genetic parameters for weight and size at birth in Boer goat. Livest. Prod. Sci. 2008; 115, 73-9.

[36] A Bharathidhasan, R Narayanan, P Gopu, A Subramanian, R Prabakaran and R Rajendran. Effect of nongenetic factors on birth weight, weaning weight and preweaning gain of Barbari goat. J. Vet. Anim. Sci. 2009; 5, 99-103.

[37] HN Hermiz, JE Alkass, AA Hobi and MK Asofi. Genetic and phenotypic parameters of body weights in Iraqi local goat and their crosses with damascus. J. Duhok Univ. 2009; 12, 189-94.

[38] BJ Restall, and WA Pattie. The inheritance of Cashmere in Australian goats. 2 Genetic parameters and breeding value. Livest. Prod. Sci. 1989; 21, 251-61.

[39] S Walkden-Brown, B Sunduimijid, B Olayemi, J Van Der Werf and A Ruvinsky. Breeding Fiber Goat for Resistance to Worm Infections. Rural Industries Research and Development Corporation, University of New England, Armidale, Australia, 2008, p. 70-87.

[40] D Allain and J Roguet. Genetic and nongenetic factors influencing mohair production traits within the national selection scheme of Angora goats in France. Livest. Prod. Sci. 2003; 82, 129-37.

[41] MAE Meybodi. The Estimate Genetic Parameters for some Economic Traits in Raieni Cashmere Goats. Ferdowsi University of Mashhad, Mashhad, Iran, 1993.

[42] EM Nejad and MA Fozi. Effect of environmental factors on fleece weight of Raeini Cashmere goats. J. Anim. Sci. Res. 2012; 22, 1-9.

[43] M Yamaki, GSS Correa, MA Silva, L Barbosa and RA Torres. Evaluation of quail carcass traits using principal component analysis. In: Proceedings of the $8^{\text {th }}$ World Congress on Genetics Applied to Livestock Production, Brazil, 2006.

[44] F Pariacote, L Ruiz, DCD Ascencao, C Borges and X Pimentel. Morphological traits of Venezuelan Creole goat, Arch. Latinoamericanos Prod. Anim. 2004; 12, S1.

[45] VAC Santos and JMT Azevedo. The use of multivariate analysis to characterize carcass and meat quality of goat kids protected by PGI "Cabrito de Barroso". Livest. Sci. 2008; 116, 70-81.

[46] A Yakubu, AE Salako and GI Ikhide. Comparative multivariate analysis of biometric traits of West African Dwarf and Red Sokoto goats. Trop. Anim. Health Prod. 2011; 43, 561-6.

[47] C Deng, R Ma, X Yue, X Lan, H Chen and C Lei. Association of IGF-1 gene polymorphism with milk yield and body size in Chinese dairy goats. Genet. Mol. Biol. 2010; 33, 266-70.

[48] CX Zhang, W Zhang, H Luo, WM Gao and Z Jia. A new single nucleotide polymorphism in the igf1 gene and its association with growth trait in the Nan Jiang Huang goat. Asian Aust. J. Anim. Sci. 2008; 21, 1073-9.

[49] SHG Wickramaratne, BR Ulmek, SP Dixit, S Kumar and MK Vyas. Use of growth hormone gene polymorphism in selecting Osmanabadi and Sangamneri goats. Trop. Agric. Res. 2010; 21, 398-411.

[50] YMA Saleha, FM Karima, MS Lamiaa and SA Ekram. Genetic polymorphism of five genes associated with growth traits in goat. Afr. J. Biotech. 2012; 2, 14738-48. 